\title{
PENGARUH DEMOGRAFI KELUARGA DALAM PENGASUHAN PERTUMBUHAN DAN PERKEMBANGAN JIWA ANAK USIA DINI
}

\author{
Rosleny Marliani ${ }^{\left.{ }^{*}\right)}$, Zulmi Ramdani ${ }^{1}$, Putri Nabhani Nurany ${ }^{1}$, Feri Indra Irawan ${ }^{1}$, Rindang \\ Ekawati ${ }^{2}$, Gina Zulfah Nur
}

${ }^{1}$ Fakultas Psikologi UIN Sunan Gunung Djati Bandung, Bandung 40614, Indonesia

${ }^{2}$ Kantor Perwakilan BKKBN Provinsi Jawa Barat, Bandung 40122, Indonesia

*)E-mail: roslenymarliani@uinsgd.ac.id

\begin{abstract}
Abstrak
Keluarga merupakan sekolah utama bagi anak untuk tumbuh berdasarkan fitrah masing-masing sehingga apa pun yang terjadi di keluarga tentunya memberikan pengaruh terhadap perkembangan anak usia dini. Studi ini bertujuan untuk menganalisis pengaruh dan melihat perbedaan dari status ekonomi, tempat tinggal, dan keterlibatan orang tua di program Bina Keluarga Balita (BKB) terhadap pengasuhan, pertumbuhan, dan perkembangan jiwa anak usia dini. Metode dalam penelitian ini adalah kuantitatif dengan menggunakan sumber data sekunder. Sebanyak 3.894 orang lbu menjadi responden pada Survei Kinerja dan Akuntabilitas Program (SKAP) 2019 Provinsi Jawa Barat. Hasil penelitian menunjukkan bahwa status ekonomi dan keterlibatan orang tua dalam program BKB berpengaruh signifikan terhadap pengasuhan, pertumbuhan, dan perkembangan jiwa anak usia dini. Selain itu, ada perbedaan signifikan antara status ekonomi orang tua yang tinggi, sedang, dan rendah. Hasil lainnya juga menunjukkan bahwa ada perbedaan signifikan antara mereka yang mengikuti program BKB dan tidak. Hasil penelitian secara umum memperkuat bahwa diperlukan fondasi yang kuat pada keluarga baik dari sisi ekonomi maupun dari segi partisipasi orang tua dalam kegiatan pembinaan dan kemasyarakatan.
\end{abstract}

Kata kunci: anak usia dini, BKB, keterlibatan orang tua, perkembangan jiwa anak, pola asuh

\section{The Effect of Family Demographic in Nurturing the Growth and Development of Mental Early Childhood}

\begin{abstract}
A family is the main school for children to grow based on their respective natures so that whatever happens in the family certainly has an influence on the development of early childhood. This study aims to analyze the effect and identify differences of economic status, residence, and parental involvement in the Family Development Program for Toddlers (BKB) on early childhood care, growth, and mental development. This study used a quantitative research method using secondary data sources. A total of 3,894 mothers became respondents in the 2019 West Java Province Performance and Accountability Survey (SKAP). The results showed that the economic status and parental involvement in the BKB program had a significant effect on early childhood parenting, growth, and mental development. In addition, there is a significant difference between the high, medium, and low economic status of parents. The other results also show a significant difference between those who participated in the BKB program and those who did not. The study results, in general, emphasize that a strong foundation is needed for the family, both in terms of financials and parental participation in coaching and community activities.
\end{abstract}

Keywords: BKB, early childhood, early childhood mental development, parental involvement, parenting

\section{PENDAHULUAN}

Proses tumbuh kembang anak usia dini berumur 1-6 tahun merupakan salah satu hal yang krusial dalam menentukan masa depan seorang anak. Proses perkembangan tersebut mencakup banyak aspek, di antaranya adalah perkembangan fisik, emosi, kognitif, sosial, moral, dan spiritual (Davis et al., 2021; Marliani, Nasrudin, Rahmawati, \& Ramdani, 2020; Permatasari \& Hastuti, 2013; Pratiwi, Hastuti, \& Muflikhati, 2018; Satrianingrum \& Andriyanti,
2020; Tsania, Sunarti, \& Krisnatuti, 2015). Aspek-aspek tersebut merupakan bagian yang sangat penting untuk mempertahankan perkembangan dan pertumbuhan mental dan jiwa seorang anak tetap optimal. Perkembangan dan pertumbuhan jiwa yang baik akan sangat memengaruhi seorang anak dalam berperilaku di kemudian hari (Zhuravlyova \& Zhuravlyov, 2015).

Pada faktanya, sebagian orang tua seringkali mengabaikan perkembangan dan pertumbuhan 
jiwa seorang anak. Hal ini terjadi karena berbagai alasan yang melatarbelakanginya di antaranya adalah belum terbentuknya suatu komunikasi yang baik di dalam keluarga, terutama peran ayah dan ibu dalam memberikan pengasuhan terhadap anak-anak mereka (Marliani et al., 2020; Ramdani, Supriyatin, \& Susanti, 2018). Selain itu, kehidupan modern yang saat ini berkembang lebih cepat juga memberikan efek terhadap berkurangnya fokus orang tua untuk mengasuh anak-anak mereka. Seperti yang dikatakan oleh Zhuravlyova dan Zhuravlyov (2015) serta Yachina (2015) bahwa dampak dari kehidupan modern saat ini menyebabkan seseorang menjadi lebih fokus pada kebutuhan dan aspek yang lebih ekonomis sehingga terkadang mengabaikan pola asuh bagi anak-anak mereka.

Perkembangan dan pertumbuhan jiwa seorang anak sangatlah penting diperhatikan oleh orang tua. Seperti yang disampaikan oleh Aziz (2017) bahwa pemenuhan aspek-aspek jiwa anak juga menentukan seorang anak dalam menyelesaikan permasalahan hidup. Sifers et al. (2012) juga menyebutkan bahwa pemenuhan yang terstruktur dan optimal dalam proses pengasuhan bisa memberikan banyak kesempatan bagi anak untuk tumbuh dan berkembang dalam kondisi yang beragam sehingga hal inilah yang mampu membekali diri mereka ketika menjalani kehidupan di masa depan nanti.

Perkembangan jiwa seorang anak tidak muncul begitu saja, harus ada penamaman dan stimulasi yang diberikan oleh orang tua sejak dini. Anak yang dibesarkan dalam pola asuh sesuai dengan perkembangannya akan mampu tumbuh lebih sehat, mengerti baik dan buruknya perilaku yang dia ambil sampai pada perilaku yang tepat dalam lingkungan sosial dan kemasyarakatan (Alfwaress \& Alomari, 2020; Dogra et al., 2021; Harris \& Corriveau, 2021; McLeigh \& Taylor, 2020). Model pengasuhan yang sesuai dan bisa dilakukan oleh orang tua sangatlah bervariasi. Mulai dari pengasuhan pada aspek spiritualitas yakni dengan meyakini keberadaan Tuhan sebagai pemberi kekuatan lalu mulai diimplementasikan pada pola asuh kepada anak-anak mereka seperti memulai berbagai aktivitas dengan berdoa, melakukan ibadah bersama sampai mengajarkan perilaku-perilaku baik yang dianjurkan oleh agama. Selain itu, pada aspek emosional, orang tua bisa mengajarkan anakanak mereka untuk menghargai teman bermain, menyapa orang yang lebih tua, memberikan kesempatan kepada anak untuk meluapkan emosinya serta aktivitas-aktivitas lain yang bisa membangkitkan perkembangan emosi anak (Christensen, 2011; Havighurst, Kehoe, Harley, Radovini, \& Thomas, 2022; Machu \& Morysova, 2016). Sementara itu, pada aspek sosial dan kognitif, anak-anak sejak dini sudah diajarkan untuk belajar sesuai dengan minat masing-masing, melatih potensi dengan aktivitas yang beragam, diperkenalkan untuk berinteraksi dengan teman-temannya dan bersekolah serta kegiatan lainnya yang menstimulasi aspek tersebut (Fowler, 1996; Metz, 1995).

Pentingnya peran orang tua dalam perkembangan jiwa anak telah lebih dulu dijelaskan oleh John Locke dalam konsep Tabula Rasa yang menjelaskan bahwa setiap manusia yang lahir ke dunia seperti sebuah kertas putih. Hal-hal yang tertuang dalam kertas putih tersebut nantinya akan sangat bergantung pada proses nurture dari lingkungan (Santrock, 2011). Konsep yang dijelaskan oleh John Locke dalam tabula rasa tersebut berkaitan dengan ajaran Islam bahwa setiap manusia yang dilahirkan ke bumi dalam keadaan fitrah atau suci. Oleh Karen itu, keluarga sebagai tempat pertama bagi anak usia dini dalam belajar harus memfasilitasi anak dengan stimulus yang baik untuk berkembang. Saputro dan Talan (2017) menjelaskan keluarga terutama orang tua sebagai role model dan pembimbing bagi anak dalam perkembangannya. Asumsi lainnya diperkuat oleh Atari, Graham, dan Dehghani (2020) yang menjelaskan mengenai lingkungan keluarga sebagai pembentuk etika, moral, dan akhlak pada seorang anak.

Peran keluarga begitu penting di dalam pertumbuhan dan perkembangan jiwa anak usia dini (Mohammadyari, 2012). Masingmasing dari anggota keluarga bisa memberikan pengaruh yang besar terhadap perkembangan tersebut. Ayah sebagai kepala keluarga berperan dalam mengajak dan memberikan contoh yang baik bagi anak-anak mereka. Ibu yang berperan sebagai tempat penyalur emosi bagi anak juga memiliki pengaruh yang signifikan terhadap perkembangan jiwa anak. Anggota keluarga lainnya yang berada di dalam rumah yang sama juga memberikan pengaruh yang besar bagi anak dalam memperoleh perkembangan yang lainnya supaya matang. Hal itulah yang membuat posisi keluarga begitu krusial bagi seorang anak (Bekui, Aziato, Ohene, \& Richter, 2020; Hashim, Yussof, \& Bahrin, 2017; Mohammadyari, 2012; Ye, Hu, Xue, Liang, \& Lu, 2021). Keluarga dengan kualitas pola asuh yang baik diharapkan akan 
membentuk anak-anak dengan kualitas yang baik pula.

Paparan yang dijelaskan pada bagian sebelumnya tentu adalah kondisi ideal yang diharapkan terjadi di keluarga dan orang tua bisa memberikan pola pengasuhan terbaik bagi anak-anak mereka. Namun pada kenyataannya, untuk memberikan pengasuhan terbaik tersebut dibutuhkan banyak faktor yang mendukungnya. Faktor-faktor yang akan dijelaskan ini seringkali menjadi permasalahan yang klasik terjadi di masyarakat saat ini sehingga menjadi penting untuk mengidentifikasi kontribusi setiap faktor tersebut dalam pengasuhan, pertembuhan, dan perkembangan jiwa anak.

Faktor-faktor tersebut di antaranya adalah keadaan perekonomian keluarga, letak geografis tempat tinggal serta jumlah anak dalam sebuah keluarga (Chairini, Hamid, Sahar, Nurachmah, \& Budhi, 2019; Hollander, Albertyn, \& Ambler, 2020). Penelitian terdahulu oleh Liu, Zhou, Cao, dan Hong (2020) serta Qi dan Wu (2020) menemukan bahwa keadaan ekonomi sebuah keluarga memiliki implikasi panjang pada kesehatan, perkembangan, dan prestasi anak di sekolah. Penelitian dari Crosnoe, Mistry, dan Elder (2002) juga turut mengungkap hal tersebut dan menegaskan bahwa ketidakberuntungan secara ekonomi membuat orang tua menjadi kurang terlibat dalam pengasuhan anak. Selain itu, letak geografis tempat tinggal suatu keluarga menurut Burchinal, Vernon-Feagans, Cox, dan Key (2008) merupakan salah satu moderator bagi berbagai resiko dalam aspek pengasuhan seperti sesntifitas dan kehangatan ibu (maternal sensitivity and warmth) juga bahasa dan aktivitas belajar (language and learning activities). Kendati demikian, penelitianpenelitian tersebut dilakukan di negara Barat sehingga perlu untuk dikaji dalam konteks Indonesia khususnya di Jawa Barat.

Di Indonesia sendiri, sudah dilakukan upaya untuk mempertahankan kualitas keluarga Indonesia seperti program BKB (Bina Keluarga Balita) dari Badan Kependudukan dan Keluarga Berencana Nasional (BKKBN) yang berfokus pada optimalisasi perkembangan anak dan pola pengasuhan dengan didasarkan pada kategori usia tertentu. Dalam pelaksanaannya, kegiatan tersebut dilakukan oleh para kader pada tingkat RW (BKKBN, 2018). Tujuan dari BKB sendiri adalah memberikan berbagai pelatihan dan psikoedukasi pada keluarga terutama ibu dalam melakukan perawatan dan pola asuh pada balita. Studi lain diperkuat oleh Wahhab (2020) bahwa kegiatan BKB membina para ibu dan juga anggota lainnya dalam keluarga terkait perkembangan dan pertumbuhan anak melalui stimulasi yang bersifat fisik, mental, intelektual, emosional, spiritual, sosial, dan moral. Ini mengindikasikan bahwa ibu atau keluarga yang memiliki keanggotaan dalam BKB mempunyai pengetahuan dan kemampuan yang mumpuni dalam memberikan stimulus bagi perkembangan jiwa anak.

Contoh lainnya dijelaskan dalam aktivitas kelompok seperti psikoedukasi dalam kegiatan BKB yang terbukti mampu meningkatkan kesadaran orang tua dengan berbagai kondisi yang dirasakan sehingga lebih memperhatikan perkembangan jiwa anak-anak mereka. Studi lain dijelaskan oleh Berge, Law, Johnson, dan Wells (2010) yang menemukan bahwa intervensi berupa psikoedukasi berkelompok pada orang tua secara signifikan dapat meningkatkan keberfungsian keluarga dan perilaku anak dalam sebuah keluarga. Lebih spesifik lagi, hal tersebut sejalan dengan penelitian mengenai efektifitas program BKB di Klojen Malang oleh Wahyuningsih, Wahyuni, dan Widianto (2020) yang menemukan bahwa implementasi program BKB sangat efektif dalam mengoptimalkan sekaligus meningkatkan keterampilan dan pemahaman orang tua dalam tumbuh kembang anak. Sementara itu, Fatmasari (2017) dalam penelitiannya yang dilakukan di Keluarahan Sako Baru, Kota Palembang, menyatakan bahwa program BKB tidak efektif karena proses psikoedukasi yang dilakukan baru sebatas menciptakan perubahan secara kognitif atau pola pikir, namun belum menciptakan perubahan perilaku pada para anggotanya.

Beberapa faktor yang dijelaskan sebelumnya menjadi prediktor yang akan diidentifikasi di dalam penelitian ini. Faktor-faktor yang dianggap berpengaruh terhadap pengasuhan, pertumbuhan, dan perkembangan seorang anak akan saling melengkapi satu dengan yang lainnya (Bekui et al., 2020; Hashim et al., 2017; Mohammadyari, 2012; Ye et al., 2021). Faktor yang bersumber dari kondisi demografi orang tua seperti keadaan ekonomi dan keberadaan tempat tinggal. Faktor lainnya adalah keinginan dan kesadaran orang tua untuk mengikuti aktivitas pemberdayaan yang ada di masyarakat sekitar. Kedua faktor awal yang dijelaskan menjadi sangat menentukan kualitas interaksi dan perkembangan yang diterima oleh anak. Anak-anak yang dibesarkan dalam kategori yang tidak optimal maka akan sangat rentan dengan perkembangan yang tidak optimal pula. Sementara itu, anak yang 
dibesarkan dalam latar belakang yang optimal dimungkinkan akan lebih banyak mendapatkan kesempatan dan ruang untuk lebih mengembangkan diri. Peneliti juga menekankan adanya faktor lingkungan yang menjadi penguat bagi kenaikan informasi, pengetahuan, dan keterampilan orang tua saat mengikuti program-program keluarga yang relevan (Chairini et al., 2019; Hollander et al., 2020).

Berdasarkan paparan yang sudah dijelaskan oleh peneliti pada bagian sebelumnya, kondisi demografi orang tua sangat berperan penting dalam mendukung pertumbuhan dan perkembangan jiwa anak. Beberapa penelitian yang sudah ada belum berfokus pada kondisi demografi orang tua sebagai faktor yang penting dalam perkembangan anak. Penelitianpenelitian tersebut misalnya seperti yang dijelaskan oleh Handayani dan Nasirin (2019) tentang faktor demografi yang memengaruhi pengambilan keputusan orang tua dalam mempunyai anak, juga oleh Nurwati (2008) yang berfokus pada keberadaan faktor demografi orang tua bagi anak untuk ikut membantu orang tua, serta penelitian yang hanya berfokus pada masalah kesehatan anak didasarkan pada kondisi demografi orang tua (Jubaedah, 2019; Rukmana \& Indawati, 2014; Solihin, Anwar, \& Sukandar, 2013). Dari sekian penelitian yang ada, belum ada yang mencoba memfokuskan faktor demografi orang tua dalam menentukan perkembangan jiwa anak mereka.

Hal yang sama juga terjadi dengan penentuan wilayah penelitian di wilayah Jawa Barat yang ditunjukkan oleh terbatasnya penelitianpenelitian terkait peran demografi keluarga untuk perkembangan anak. Mayoritas dari penelitian yang ada hanya menggunakan contoh penelitian yang cenderung terbatas sehingga belum mampu menangkap secara keseluruhan situasi yang terjadi di wilayah Jawa Barat (Hayati \& Mamat, 2014; Nurwati, 2008; Rahmat, 2019). Fokus studi ini dilakukan di wilayah Jawa Barat karena keberadaan Jawa Barat sebagai wilayah dengan jumlah penduduk terbanyak di Indonesia sehingga akan berpotensi menjadi model pengembangan keluarga bagi wilayah lainnya. Selain itu, keberagaaman demografi dan struktur permasalahan yang terjadi di Jawa Barat termasuk ke dalam kriteria yang cocok untuk diidentifikasi sehingga bisa menjadi urgensi bagi pemangku kebijakan untuk menerapkan peraturan yang cocok dalam rangka meningkatkan kesejahteraan penduduk di Indonesia (BKKBN, 2018, 2020; BPS, 2012).
Studi-studi sejenis yang dijelaskan tersebut belum mampu menunjukkan informasi yang cukup komprehensif dalam menjelaskan faktorfaktor penting dalam keluarga sebagai penentu perkembangan jiwa anak. Kebanyakan studi hanya berupaya melihat faktor tersebut dan urgensinya terhadap perkembangan keluarga itu sendiri. Berdasarkan dasar pertimbangan yang dijelaskan sebelumnya, studi ini bertujuan untuk menganalisis pengaruh status ekonomi keluarga, tempat tinggal, dan keterlibatan orang tua dalam program BKB terhadap pengasuhan, pertumbuhan, dan perkembangan jiwa pada anak usia dini, serta mengidentifikasi perbedaan status ekonomi orang tua, tempat tinggal orang tua, dan keterlibatan orang tua dalam BKB dalam aspek pengasuhan, pertumbuhan, dan perkembangan jiwa anak usia dini. Sementara itu, dari hasil analisis yang dilakukan pada penjabaran sebelumnya, peneliti berasumsi bahwa faktor ekonomi, tempat tinggal, dan keterlibatan orang tua dalam program BKB akan berpengaruh terhadap pengasuhan, pertumbuhan, dan perkembangan jiwa anak. Hipotesis lainnya ialah bahwa terdapat perbedaan yang signifikan berdasarkan level ekonomi orang tua, tempat tinggal, dan terlibat atau tidak terlibatnya orang tua terhadap pengasuhan, pertumbuhan, dan perkembangan jiwa anak usia dini.

\section{METODE}

Studi ini menggunakan pendekatan kuantitatif. Data yang digunakan merupakan secondary data resources (SDR), yaitu sebuah penelitian dengan menggunakan data sekunder yang sudah diperoleh pada hasil survei pada kegiatan sebelumnya. Penggunaan data SDR ini sangat tepat dilakukan karena peneliti mampu mengidentifikasi model pemecahan masalah berbasis pada data yang sudah ada tanpa harus melakukan pengambilan data secara langsung kembali (Aslan \& Kosir, 2021). Pendekatan seperti ini sangat cocok dipilih terutama di tengah situasi pandemi seperti ini.

Studi ini melibatkan ibu dari keluarga yang mempunyai balita dan bertempat tinggal di wilayah Jawa Barat, yang merupakan salah satu wilayah dengan jumlah penduduk paling banyak di Indonesia. Penentuan contoh dilakukan secara sistematis mengacu pada pengambilan contoh acak (random sampling) yang didasarkan pada cluster sampling atau jumlah penyebaran responden yang tinggal di wilayah tersebut. Penelitian ini menggunakan responden yang diambil berdasarkan kesepakatan yang sudah dilakukan melalui kegiatan pengisian informed consent terlebih 
dahulu yaitu kegiatan kesepakatan antara pengambil data dengan subjek untuk bersedia mengikuti kegiatan penelitian sehingga dalam hal ini penelitian memenuhi kriteria yang diharapkan.

Data yang digunakan berdasarkan dari Survei Kinerja dan Akuntabilitas Program (SKAP) pada tahun 2019 yang dilakukan oleh tim peneliti dari Kantor Perwakilan Badan Kependudukan dan Keluarga Berencana Nasional (BKKBN) pada tahun 2019 di wilayah Provinsi Jawa Barat (BKKBN, 2020). Data yang dijadikan sebagai bahan analisis merupakan data pengasuhan, pertumbuhan, dan perkembangan jiwa anak. Variabel tersebut terdiri dari 8 pernyataan operasional yang menggambarkan kondisi orang tua dalam memberikan pengasuhan melalui berbagai kegiatan bagi anak-anak mereka. Adapun untuk contoh pernyataan dalam variabel tersebut yaitu "Apakah orang tua menemani anak bermain?", "Apakah orang tua mengajari anak beribadah?", dan "Apakah orang tua mengajari anak menghormati/menghargai orang lain?". Jawaban yang dipakai dalam pernyataan tersebut berupa pilihan nominal yang terdiri dari Ya dan Tidak. Variabel pengasuhan, pertumbuhan, dan perkembangan jiwa anak didasarkan pada hasil modifikasi teori dari Survei Demografi dan Kesehatan Indonesia (SDKI) oleh BPS (2012), Yachina (2015), dan Zhuravlyova dan Zhuravlyov (2015). Pengujian reliabilitas awal dilakukan dengan memperoleh hasil koefisien reliabilitas di atas 0,7 dengan variasi daya beda setiap itemnya berada pada kategori yang memuaskan.

Variabel pengasuhan, pertumbuhan, dan perkembangan jiwa anak dijadikan sebagai variabel terikat sedangkan variabel bebas meliputi karakteristik demografi subjek berupa status ekonomi, wilayah tempat tinggal, dan keterlibatan dalam program BKB. Status ekonomi didefinisikan secara operasional sebagai jumlah penghasilan yang diperoleh dalam keluarga setiap bulannya (Ayah, Ibu, atau kepala keluarga lainnya). Untuk variabel status ekonomi dibagi menjadi level tinggi, sedang, dan rendah. Pembagian kategori tersebut didasarkan pada perhitungan data rata-rata dan standar deviasi pada hasil secara keseluruhan (Azwar, 2016).

Tempat tinggal dilihat dari posisi rumah atau lokasi rumah yang ditinggali keluarga saat ini, termasuk ke dalam wilayah perkotaan (ibu kota) atau wilayah pedesaan (daerah pinggiran ibu kota kabupaten). Untuk data tempat tinggal dibedakan menjadi perkotaan dan pedesaan.
Untuk keterlibatan dalam BKB dibedakan menjadi dua juga yaitu subjek terlibat dan subjek tidak terlibat. Keterlibatan ini dilihat dari informasi pendaftaran dan keikutsertaan ibu dalam kegiatan BKB. Peneliti memastikan bahwa variabel-variabel bebas sudah divalidasi oleh ahli sehingga penentuan definisi operasional ini dapat dinyatakan sudah merepresentasikan tujuan yang ingin dikukur.

Analisis data mengacu pada beberapa tahapan analisis. Uji regresi berganda dilakukan untuk melihat pengaruh variabel bebas terhadap variabel terikat. Uji beda digunakan untuk melihat perbedaan di antara kelompok yang ada. Aplikasi SPSS digunakan untuk menganalisis data penelitian. Untuk proses interpretasi data, peneliti menyesuaikan dengan hasil penelitian dan tujuan yang ingin dicapai dalam studi ini.

\section{HASIL}

Penelitian ini merupakan hasil pengambilan data sekunder yang digunakan dalam rangka untuk memberikan informasi terkait faktor-faktor yang memengaruhi pengasuhan, perkembangan, dan perkembangan jiwa pada anak usia dini. Data sekunder yang dimaksud adalah data Survei Kinerja dan Akuntabilitas Program (SKAP) pada tahun 2019. Peneliti terlebih dahulu akan menyajikan data demografi dari responden yang terlibat. Sebanyak 3.894 orang terlibat dalam studi ini dan berstatus sebagai seorang ibu. Seluruh responden yang terlibat sudah disesuaikan dengan karakteristik yang ditentukan oleh peneliti sebelumnya (Tabel 1).

Tabel 1 Data demografi responden

\begin{tabular}{lrr}
\hline Data demografi & $\begin{array}{c}\text { Jumlah } \\
\text { responden }\end{array}$ & $\begin{array}{c}\text { Persentase } \\
(\%)\end{array}$ \\
\hline Status ekonomi & & 40,3 \\
Tinggi & 1.567 & 46,9 \\
Sedang & 1.827 & 12,8 \\
Rendah & 500 & \\
Tempat tinggal & & 65,9 \\
$\quad$ Perkotaan & 2.567 & 34,1 \\
Pedesaan & 1.327 & \\
Keterlibatan & & 42,2 \\
dalam BKB & & 57,8 \\
Terlibat & 1.623 & 85 \\
Tidak terlibat & 2.271 & 14,1 \\
Jumlah balita & & 0,9 \\
1 orang & 3.311 & \\
2 orang & 548 & \\
3 orang & 35 &
\end{tabular}


Tabel 2 Uji normalitas tiap variabel

\begin{tabular}{lcc}
\hline \multicolumn{1}{c}{ Variabel } & $\begin{array}{c}\text { Kolmogorov } \\
\text { smirnov }\end{array}$ & Keterangan \\
\hline $\begin{array}{l}\text { Pengasuhan, } \\
\text { pertumbuhan, dan } \\
\text { perkembangan jiwa }\end{array}$ & 0,000 & Tidak normal \\
$\begin{array}{l}\text { anak } \\
\text { Status ekonomi }\end{array}$ & 0,000 & Tidak normal \\
Tempat tinggal & 0,000 & Tidak normal \\
Keterlibatan BKB & 0,000 & Tidak normal \\
\hline
\end{tabular}

Tabel 1 menunjukkan perbedaan jumlah responden berdasarkan data demografi yang ada. Jika dilihat dari status ekonomi responden, responden pada status ekonomi yang tinggi kurang lebih mempunya jumlah yang sama banyaknya dengan responden pada status ekonomi sedang, berbeda dengan responden yang berstatus ekonomi rendah sebanyak 12,8 persen saja. Untuk lokasi tempat tinggal, responden yang berada di wilayah perkotaan mempunyai jumlah yang lebih banyak yaitu sebesar 65,9 persen, sedangkan yang di pedesaan sebesar 34,1 persen. Untuk keterlibatan dalam program BKB, mereka yang tidak terlibat ternyata lebih banyak dibandingkan yang terlibat. Sementara itu, jumlah balita (bawah lima tahun) didominasi oleh responden yang mempunyai balita 1 orang yaitu sebanyak 85 persen, dan sisanya responden dengan 2 orang balita $(14,1 \%)$ dan 3 orang balita $(0,9 \%)$.

Uji Normalitas Data. Jika mengacu pada Tabel 2 , semua variabel berada pada kondisi tidak normal ( $p$ dikatakan normal jika $>0,05$ ). Dengan demikian, untuk melakukan analisis lanjutannya peneliti mengalihkan proses pengujian dalam ranah nonparametrik. Untuk melihat pengaruh masing-masing variabel digunakan uji regresi berganda, analisis uji beda 2 kategori menggunakan uji Man Whitney, sedangkan uji beda 3 kategori menggunakan analisis Kruskal Wallis.

Tabel 3 Pengaruh variabel bebas terhadap variabel terikat

\begin{tabular}{|c|c|c|c|c|c|}
\hline \multirow{2}{*}{ Model } & \multicolumn{2}{|c|}{$\begin{array}{c}\text { Unstandardiz } \\
\text { ed }\end{array}$} & \multirow{2}{*}{$\begin{array}{c}\begin{array}{c}\text { Standardiz } \\
\text { ed }\end{array} \\
\text { Beta }\end{array}$} & \multirow{2}{*}{$\mathrm{t}$} & \multirow[b]{2}{*}{ Sig. } \\
\hline & $B$ & $\begin{array}{l}\text { Std. } \\
\text { Error }\end{array}$ & & & \\
\hline (Constant) & $\begin{array}{r}2,85 \\
1\end{array}$ & 0,200 & & $\begin{array}{r}14,27 \\
7\end{array}$ & $\begin{array}{r}0,00 \\
0\end{array}$ \\
\hline $\begin{array}{l}\text { Tempat } \\
\text { tinggal }\end{array}$ & $\begin{array}{r}0,02 \\
4\end{array}$ & 0,073 & $-0,006$ & 0,337 & $\begin{array}{r}0,73 \\
6\end{array}$ \\
\hline $\begin{array}{l}\text { Status } \\
\text { ekonomi }\end{array}$ & $\begin{array}{r}0,15 \\
4\end{array}$ & 0,051 & 0,051 & 3,030 & $\begin{array}{r}0,00 \\
2\end{array}$ \\
\hline $\begin{array}{l}\text { Keterlibat } \\
\text { an BKB }\end{array}$ & $\begin{array}{r}0,49 \\
3\end{array}$ & 0,066 & 0,120 & 7,465 & $\begin{array}{r}0,00 \\
0\end{array}$ \\
\hline
\end{tabular}

Tabel 4 Hasil uji beda tiap variabel

\begin{tabular}{ccc}
\hline Variabel X & Sig. & Keterangan \\
\hline Status ekonomi & 0,000 & $\begin{array}{c}\text { Terdapat perbedaan } \\
\text { signifikan } \\
\text { Tidak terdapat } \\
\text { perbedaan }\end{array}$ \\
Tempat tinggal & 0,122 & $\begin{array}{c}\text { Terdapat perbedaan } \\
\text { signifikan }\end{array}$ \\
$\begin{array}{l}\text { Keterlibatan } \\
\text { dalam BKB }\end{array}$ & 0,000 & Keterangan. $p<0,05=$ terdapat perbedaan
\end{tabular}

Uji Regresi Berganda. Untuk melihat signifikansi dan peran dari setiap variabel terhadap pengasuhan, pertumbuhan, dan perkembangan jiwa anak bisa dilihat pada Tabel 3.

Informasi pada Tabel 3 menunjukkan bahwa di antara variabel-variabel bebas yang diujikan terhadap variabel terikat, hanya terdapat 2 variabel bebas yang berpengaruh signifikan terhadap variabel terikat yaitu status ekonomi dan keterlibatan dalam program BKB $(p<0,05)$. Sementara itu, variabel tempat tinggal tidak berpengaruh terhadap variabel terikat. Hasil yang disajikan pada Tabel 3 tersebut disesuaikan dengan tujuan penelitian yang ingin melihat secara parsial ada atau tidaknya pengaruh variabel bebas terhadap variabel terikat.

Uji Beda Kelompok. Untuk melihat lebih spesifik dari masing-masing kategori pada variabel bebas, maka peneliti melakukan uji beda menggunakan analisis Man Whitney dan Kruskal Wallis. Hasil uji beda pada Tabel 4 menunjukkan bahwa terdapat perbedaan yang signifikan antara responden yang mempunyai perekonomian tinggi, sedang, dan rendah. Begitu juga jika dilihat dari variabel keterlibatan, ada perbedaan signifikan antara responden yang terlibat dengan responden yang tidak terlibat dalam program BKB. Sementara itu, variabel tempat tinggal tidak menunjukkan perbedaan di antara mereka yang tinggal di kota dan di desa.

\section{PEMBAHASAN}

Pengasuhan, pertumbuhan, dan perkembangan jiwa anak merupakan salah satu aspek penting yang terbentuk dari sebuah keluarga (Oktriyanto, 2016). Optimalisasi yang dilakukan oleh orang tua di rumah akan menjadi fondasi yang terus dipegang teguh oleh seorang anak hingga kelak berusia dewasa. Namun, pada kenyataannya tidak semua keluarga mampu memfasilitasi perkembangan jiwa anak dengan optimal. Dalam penelitian ini ditemukan bahwa beberapa faktor yang berpengaruh terhadap pengasuhan, pertumbuhan, dan perkembangan 
jiwa anak usia dini dalam sebuah keluarga di antaranya adalah status ekonomi dan keterlibatan orang tua dalam BKB atau kegiatan pembinaan yang berkaitan dengan perkembangan anak. Hasil penelitian memperlihatkan perbedaan signifikan dalam perlakuan tumbuh kembang spiritual anak usia dini berdasarkan status ekonomi yang dilihat dari indeks kekayaan orang tua.

Secara teoritis, kekayaan merupakan manifestasi penghasilan, uang, atau barang bernilai yang dimiliki seseorang. Studi sebelumnya menempatkan kekayaan sebagai faktor yang sangat menentukan kualitas hidup dan keberlanjutan hidup seseorang (Chairini et al., 2019; Hollander et al., 2020). Faktanya, kondisi ekonomi orang tua yang baik tentunya akan menghadirkan kenyamanan, ketercukupan, dan ketersediaan bahan pangan serta memberikan modal berharga dalam memberikan pengasuhan kepada anak. Sementara itu, kondisi ekonomi orang tua yang tidak mumpuni mungkin akan berdampak terhadap tidak optimalnya pola pengasuhan yang diberikan (Xia, 2020). Hal ini dikarenakan bagi orang tua dengan penghasilan yang rendah, fokus utama mereka adalah pada pemenuhan kebutuhan dasar sehari-hari sehingga perkembangan anak khususnya perkembangan spiritual tidak menjadi prioritas. Hal ini kemudian menghasilkan adanya perbedaan antara pola pengasuhan yang diberikan oleh mereka yang secara ekonomi mumpuni dengan yang tidak (Chairini et al., 2019; Hollander et al., 2020).

Secara tidak langsung faktor ekonomi ini menentukan kualitas hidup dan perkembangan seluruh anggota keluarga. Begitu juga dengan studi sebelumnya oleh Rowe (2008) yang menegaskan bahwa status ekonomi orang tua memengaruhi penguasaan bahasa anak karena dimediasi oleh pengetahuan orang tua. Hasil penelitian tersebut menunjukkan bahwa situasi kekayaan yang menguntungkan bagi sebagian orang tua akan berpotensi positif dalam mengoptimalisasi pertumbuhan dan pengasuhan bagi anak-anak mereka. Artinya, semakin tinggi status ekonomi orang tua maka perlakuan perkembangan oleh orang tua semakin baik karena orang tua memiliki pengetahuan yang lebih baik. Dengan kekayaan yang dimiliki, setiap orang tua mampu mengembangkan potensi yang dimiliki oleh anak. Namun, diperlukan penelitian yang lebih mendalam untuk memastikan bahwa optimalisasi yang dihasilkan dari kondisi ekonomi tersebut berpengaruh secara langsung atau dibutuhkan variabel lain yang memediasi hal tersebut.

Kemudian, dalam hasil penelitian yang sudah dilakukan terdapat adanya perbedaan yang signifikan antara orang tua yang terlibat aktif dalam BKB dengan orang tua yang tidak terlibat dalam BKB pada pengasuhan, pertumbuhan, dan perkembangan jiwa anak usia dini. Hasil penelitian tersebut sejalan dengan berbagai hasil penelitian yang sudah dilakukan sebelumnya. Contohnya adalah penelitian yang dilakukan oleh Oktriyanto (2016) yang menunjukkan bahwa adanya BKB di tengahtengah masyarakat terbukti telah membantu keluarga dalam mendukung tumbuh kembang anak. Menurutnya, orang tua yang terlibat dalam aktivitas BKB memiliki anak yang perkembangannya lebih baik dibandingkan dengan orang tua yang bukan anggota BKB.

Penelitian lainnya menunjukkan adanya efektivitas program BKB di Klojen Malang oleh Wahyuningsih et al. (2020) yang menemukan bahwa implementasi program BKB sangat efektif untuk meningkatkan kemampuan dan pengetahuan orang tua dalam tumbuh kembang anak. Hal tersebut tidak terlepas dari tujuan BKB untuk meningkatkan pengetahuan dan kemampuan orang tua atau anggota keluarga lain dalam hal pertumbuhan dan perkembangan anak usia balita dalam berbagai aspek termasuk dalam aspek spiritual (Wahhab, 2020). Selain adanya efektifitas dari $\mathrm{BKB}$, hasil penelitian terdahulu menunjukkan bahwa perlakuan yang diberikan oleh orang tua dalam rangka mendukung tumbuh kembang anaknya sangat bergantung pada inisiatif dan keaktifan orang tua dalam mencari sumber informasi dan pengetahuan mengenai proses perkembangan anak (Gralewski \& Jankowska, 2020; Zhao \& Yang, 2021). Dengan demikian, bukan hanya sekedar keanggotaannya saja yang diperlukan tapi juga kesadaran dari dalam diri masing-masing orang tua mengenai pentingnya mengikuti program BKB ini. Dibutuhkan perubahan pola pikir yang sebelumnya menganggap pertumbuhan dan perkembangan anak bukan hal yang penting menjadi pemahaman bahwa dalam pengasuhan dibutuhkan ilmu. Semakin aktif orang tua dalam kegiatan BKB maka akan semakin baik pengasuhan, pertumbuhan, dan perkembangan jiwa anaknya.

Di sisi lain, hal ini menunjukkan adanya efektifitas proses psikoedukasi oleh para kader BKB kepada para anggotanya dan juga kesiapan para anggota dalam mengikuti pembinaan dan psikoedukasi. Tercapainya 
tujuan dalam sebuah program membutuhkan integrasi antara kompetensi para kader dan kualitas dari anggota atau peserta yang mengikuti program tersebut. Sebagaimana yang diungkapkan oleh Christensen (2011) dalam penelitiannya bahwa kualitas yang harus dimiliki oleh seorang individu agar program psikoedukasi bisa menjadi efektif di antaranya adalah kemampuan dalam komunikasi yang efektif, keterlibatan yang aktif, komunikasi yang berkualitas, konsistensi dalam nilai dan norma yang dianut, integrasi yang baik dalam pembagian peran orang tua, kontrol dan pengaruh yang konstruktif bagi anak, dan pemenuhan tugas yang baik dalam program pembinaan.

Efektifitas program BKB ini seharusnya mampu untuk dirasakan manfaatnya oleh lebih banyak orang tua. Sayangnya keterlibatan orang tua dalam progam BKB masih tergolong rendah. Menurut Christensen (2011), variabel yang mungkin memengaruhi keikutsertaan partisipan dalam sebuah program psikoedukasi di antaranya adalah waktu yang dibutuhkan untuk mengikuti rangkaian kegiatan, lokasi dilakukannya kegiatan, metode perekrutan anggota, serta keadaan dan karakteristik unik yang dimiliki oleh sebuah grup. Dengan demikian, dapat dipahami jika keikutsertaan orang tua dalam BKB tidak selalu tinggi karena prioritas dan ketersediaan waktu setiap orang tua berbeda-beda. BKKBN sebagai institusi yang menggalakkan program BKB ini harus memperhatikan variabel tersebut untuk meningkatkan keikutsertaan masyarakat dalam BKB. Hal ini dapat dilakukan dengan mempertimbangkan durasi program yang disesuaikan dengan konteks masyarakat yang menjadi sasaran program. Kemudian, lokasi bisa menggunakan tempat yang mudah dijangkau sehingga memudahkan akses peserta program. BKKBN juga bisa melakukan inovasi dalam melakukan perekrutan sehingga keanggotaan menjadi meningkat. Pada dasarnya, variabel tersebut harus bisa dilaksanakan secara kontekstual dan menyesuaikan dengan kondisi masing-masing masyarakat yang menjadi sasaran program.

Penelitian yang telah dilakukan juga memperhitungkan lokasi tempat tinggal yaitu kota dan desa. Hasil analisis yang telah dilakukan menunjukkan bahwa daerah yang menjadi tempat tinggal subjek baik kota maupun desa tidak menentukan perbedaan pengasuhan orang tua terhadap perkembangan spiritual anak. Seperti halnya menurut Madyawati (2016), banyak faktor yang dianggap bisa memengaruhi pola pengasuhan anak, yaitu kondisi sosial dan perekonomian orang tua, latar belakang pendidikan, keyakinan dalam beragama yang dianut oleh orang tua, kepribadian, dan jumlah anak. Berdasarkan pernyataan tersebut, tempat tinggal bukanlah salah satu faktor signifikan yang menentukan cara orang tua memberikan pengasuhan kepada anaknya (Handayani, 2019).

Isu perbedaan tempat tinggal desa dan kota yang menyebutkan bahwa kota memiliki peradaban yang maju, modern, dan terbuka dibanding dengan kehidupan di desa, memang bukanlah hal yang salah. Namun, terdapat faktor lain yang lebih menonjol dan signifikan yang berperan dalam pengasuhan orang tua terhadap anak. Cara orang tua yang tinggal di kota dalam mengasuh anaknya mungkin saja banyak diterapkan oleh orang tua yang juga tinggal di desa. Pada dasarnya, pola asuh orang tua tergantung dari dari pengalaman, pendidikan, nilai yang dianut, dan lainnya. Penelitian ini menunjukkan perlakuan orang tua terhadap tumbuh kembang anak didasarkan pada kesadaran orang tua terhadap pentingnya nilai-nilai positif (Madyawati, 2016) yang tumbuh dalam diri anak. Dalam hal ini mungkin saja orang tua yang tinggal di perkotaan dengan lingkungan yang maju tidak begitu memperhatikan nilai-nilai yang mendalam pada anak. Namun demikian, ketika orang tua baik di kota maupun di desa sadar akan pentingnya perkembangan jiwa yang baik bagi anak, maka dapat dipastikan orang tua akan menerapkan pengasuhan yang baik pula untuk tumbuh kembang anak khususnya pada anak usia dini.

Penelitian ini dilakukan dengan menggunakan data sekunder yang sudah ada sehingga peneliti tidak dapat mengidentifikasi lebih lanjut faktor-faktor yang lebih determinan secara lebih mendalam. Selain itu, penelitian ini tidak melibatkan variabel psikologis lainnya yang dianggap erat kaitannya dengan pengasuhan, pertumbuhan, dan perkembangan jiwa anak dibandingkan dengan variabel demografi. Dengan demikian, tinjauan awal secara kualitatif juga sangat diperlukan untuk melengkapi asumsi yang dibangun oleh peneliti. Di samping itu, studi lanjutan untuk memperkuat hasil dalam studi ini juga diperlukan di masa depan.

\section{SIMPULAN DAN SARAN}

Penelitian ini menyimpulkan bahwa status ekonomi dan keterlibatan orang tua dalam program BKB berpengaruh signifikan terhadap pengasuhan, pertumbuhan, dan perkembangan jiwa anak usia dini. Sementara itu, tempat 
tinggal orang tua tidak berpengaruh signifikan terhadap pengasuhan, pertumbuhan, dan perkembangan jiwa anak usia dini. Hasil penelitian juga menunjukkan bahwa terdapat perbedaan yang signifikan antara orang tua yang berada pada status ekonomi tinggi, sedang, dan rendah dalam pengasuhan, pertumbuhan, dan perkembangan jiwa anak usia dini. Keterlibatan orang tua dalam program Bina Keluarga Balita (BKB) juga berbeda secara signifikan. Status ekonomi yang tinggi berdasarkan kategorisasi peneliti dan partiisipasi aktif dalam kegiatan pemberdayaan masyarakat mempunyai pengaruh yang signifikan terhadap pola asuh yang diberikan.

Hasil penelitian ini memberikan informasi yang cukup komprehensif dan tidak hanya menjadikan keluarga sebagai elemen penting dalam perkembangan anak semata, tetapi memunculkan suatu kajian baru bahwa faktorfaktor demografi ikut berkontribusi dalam perkembangan tersebut. Oleh karena itu, informasi ini perlu menjadi perhatian serius bagi pemangku kebijakan dalam meningkatkan kesejahteraan keluarga Indonesia. Penelitian selanjutnya perlu meningkatkan variasi responden penelitian yang akan diuji dan perlu melibatkan atribut-atribut psikologis yang lebih abstrak yang kadang tidak bisa dilihat secara langsung di lapangan. Studi selanjutnya juga perlu diperkuat dengan data lapangan terkini sesuai dengan tujuan yang ingin dicapai peneliti.

\section{ACKNOWLEDMENT}

Studi ini merupakan hasil Kerjasama yang dilakukan oleh tim dari Fakultas Psikologi UIN Sunan Gunung Djati Bandung bersama dengan Kantor Perwakilan Badan Kependudukan dan Keluarga Berencana Nasional (BKKBN) Provinsi Jawa Barat.

\section{DAFTAR PUSTAKA}

Alfwaress, F., \& Alomari, M. (2020). Social and religious attitudes of Jordanian parents toward children born with orofacial clefts. International Journal of Pediatric Otorhinolaryngology, 137(October), 110222. doi:10.1016/j.ijporl.2020.110222

Aslan, M., \& Kosir, S. (2021). Survey data showing the influence of school attachment among secondary school students in Albania. Data in Brief, 35(April). doi:10.1016/j.dib.2021.106949
Atari, M., Graham, J., \& Dehghani, M. (2020). Foundations of morality in Iran. Evolution and Human Behavior, 41(5), 367-384.

doi:10.1016/j.evolhumbehav.2020.07.0 14

Aziz, S. (2017). Pendidikan spiritual berbasis sufistik bagi anak usia dini dalam keluarga. Dialogia: Jurnal Studi Islam dan Sosial, 15(1), 131-149. doi:10.21154/dialogia.v15i1.1188

Azwar, S. (2016). Konstruksi tes kemampuan kognitif. Yogyakarta, ID: Pustaka Belajar.

Bekui, B. A., Aziato, L., Ohene, L. A., \& Richter, M. S. (2020). Psychological and spiritual wellbeing of family caregivers of children with cancer at a teaching hospital in Ghana. International Journal of Africa Nursing Sciences, 13. doi:10.1016/j.ijans.2020.100231

Berge, J. M., Law, D. D., Johnson, J., \& Wells, M. G. (2010). Effectiveness of a psychoeducational parenting group on child, parent, and family behavior: A pilot study in a family practice clinic with an underserved population. Families, Systems \& Health: The Journal of Collaborative Family Healthcare, 28(3), 224-235. doi:10.1037/a0020907

Burchinal, M., Vernon-Feagans, L., Cox, M., \& Key. (2008). Cumulative social risk, parenting, and infant development in rural low-income communities. Parenting, Science and Practice, 8(1), 41-69. doi:10.1080/15295190701830672

[BKKBN] Badan Kependudukan dan Keluarga Berencana Nasional. (2018). Peraturan kepala badan kependudukan dan keluarga berencana nasional tentang pengelolaan bina keluarga balita Holistik Integratif (HI). Jakarta, ID: BKKBN

[BKKBN] Badan Kependudukan dan Keluarga Berencana Nasional. (2020). Survei kinerja dan akuntabilitas program KKBPK 2019. Jakarta, ID: BKKBN

[BPS] Biro Pusat Statistik. (2012). Survei kesehatan dan demografi Indonesia. Retrieved from https://sirusa.bps.go.id/sirusa/index.php /kuesioner/39

Chairini, R., Hamid, A. Y., Sahar, J., Nurachmah, E., \& Budhi, T. B. (2019). Strengthening resilience in families of 
street adolescents with embedding spiritual values. Enfermeria Clinica, 29(2) doi:10.1016/j.enfcli.2019.06.009

Christensen, L. A. (2011). Effects of group psychoeducation for parents of at-risk adolescents undergraduate. (Tesis, University of North Florida). https://digitalcommons.unf.edu/etd/144.

Crosnoe, R., Mistry, R. S., \& Elder, G. H. (2002). Economic disadvantage, family dynamics, and adolescent enrollment in higher education. Journal of Marriage and Family, 64(3), 690-702. doi:10.1111/j.1741-3737.2002.00690.x

Davis, D., Miller, D., Mrema, D., Matsoai, M., Mapetia, N., Raikes, A., \& Burton, A. (2021). Understanding perceptions of quality among early childhood education stakeholders in Tanzania and Lesotho: A multiple qualitative case study. Social Sciences and Humanities Open, 4, 100153. doi:10.1016/j.ssaho.2021.100153

Dogra, S. A., Rai, K., Barber, S., McEachan, R. R. C., Adab, P., \& Sheard, L. (2021). Delivering a childhood obesity prevention intervention using Islamic religious settings in the UK: What is most important to the stake holders? Preventive Medicine Reports, 22(June). doi:10.1016/j.pmedr.2021.101387

Fatmasari, Y. (2017). Efektifitas penyuluhan bina keluarga balita dalam upaya meningkatkan keterampilan pola asuh orang tua di bkb al-muntaha kelurahan sako baru kota Palembang (Skripsi, UIN Raden Fatah Palembang). http://repository.radenfatah.ac.id/4977/

Gralewski, J., \& Jankowska, D. M. (2020). Do parenting styles matter? Perceived dimensions of parenting styles, creative abilities and creative self-beliefs in adolescents. Thinking Skills and Creativity, 38. doi:10.1016/j.tsc.2020.100709

Handayani, R. (2019). Pengaruh lingkungan tempat tinggal dan pola asuh orang tua terhadap motivasi belajar siswa sekolah dasar. Jurnal Tunas Bangsa, 6(1), 1526.

Handayani, N., \& Nasirin, C. (2019). Pengaruh sosial demografi terhadap jumlah anak yang diinginkan di NTB. Jurnal Midwifery Update (MU), 1(2), 70-78.
Harris, P. L., \& Corriveau, K. H. (2021). Beliefs of children and adults in religious and scientific phenomena. Current Opinion in Psychology, 40(August), 20-23. doi:10.1016/j.copsyc.2020.08.003

Hashim, R., Yussof, H., \& Bahrin, N. L. Z. (2017). Religious perceptions on use of humanoid for spiritual augmentation of children with autism. Procedia Computer Science, 105, 353-358. doi:10.1016/j.procs.2017.01.233

Havighurst, S. S., Kehoe, C., Harley, A. E., Radovini, A., \& Thomas, R. (2022). A randomizes controlled trial of an emotion socialization parenting program and its impact on parenting, children's behavior and parent and child stress cortisol: Tuning in to toddlers. Behavior Research and Therapy, 149, 104016. doi:10.1016/j.brat.2021.104016

Hayati, M., \& Mamat, N. (2014). Pengasuhan dan peran orang tua serta pengaruhnya terhadap perkembangan sosial emosional anak di paud banda aceh, Indonesia. Buah Hati, 1(2), 16-30. doi:10.46244/buahhati.v1i2.523

Hollander, Dd., Albertyn, R., \& Ambler, J. (2020). Palliation, end-of-life care and burns, practical issues, spiritual care and care of the family (A narrative review II). African Journal of Emergency medicine, 10, 256-260. doi:10.1016/j.afjem.2020.07.011

Jubaedah, E. (2019). Analisis kependudukan Provinsi Jawa Barat. Jurnal Industri Elektro dan Penerbangan, 8(1).

Liu, Q., Zhou, N., Cao, H., \& Hong, X. (2020). Family socioeconomic status and Chinese young children's social competence: Parenting processes as mediators and contextualizing factors as moderators. Children and Youth Services Review, 118, 105356. doi:10.1016/j.childyouth.2020.105356

Machu, E., \& Morysova, D. (2016). Analysis of the emotion of fear in gifted children and its use in teaching practice. Procedia Social and behavioral Sciences, 217, 222-228. doi:10.1016/j.sbspro.2016.02.071

Madyawati, L. (2016). Strategi pengembangan bahasa pada anak. Jakarta, ID: Prenadamedia Group.

Marliani, R., Nasrudin, E., Rahmawati, R., \& Ramdani, Z. (2020). Regulasi emosi, 
stres, dan kesejahteraan psikologis: Studi pada ibu work from home dalam menghadapi pandemi COVID-19. In Karya Tulis IImiah LP2M UIN SGD Bandung.

McLeigh, J. D., \& Taylor, D. (2020). The role of religious institutions in preventing, eradicating, and mitigating violence against children. Child Abuse \& Neglect, 110(1), 104313. doi:10.1016/j.chiabu.2019.104313

Metz, K. E. (1995). Reassessment of developmental constraints on children's science instruction. Review of Educational Research, 65, 93-127. doi:10.3102/00346543065002093

Mohammadyari, G. (2012). Relationship between parent's spiritual intelligence, level of education and children's mental health. Procedia-Social and Behavioural Sciences, 69 (December), 2114-2118. doi:10.1016/j.sbspro.2012.12.174

Nurwati, N. (2008). Pengaruh kondisi sosial dan ekonomi keluarga terhadap motivasi pekerja anak dalam membantu keluarga di Kabupaten Cirebon, Jawa Barat. Jurnal Kependudukan Padjajaran, 10(2), 112-121.

Oktriyanto. (2016). Partisipasi keluarga anggota bina keluarga balita (BKB) dalam pengasuhan dan tumbuh kembang anak usia 0-6 tahun. Jurnal Kependudukan Indonesia, 1(2), 133142. doi:10.14203/jki.v11i2.192

Permatasari, C. L., \& Hastuti, D. (2013). Nilai budaya, pengasuhan penerimaanpenolakan, dan perkembangan sosial anak usia 3-5 tahun pada keluarga Kampung Adat Urug, Bogor. Jurnal IImu Keluarga \& Konsumen, 6(2), 9199. doi:10.24156/jikk.2013.6.2.91

Pratiwi, I., Hastuti, D., \& Muflikhati, I. (2018). Penyesuaian keluarga, pengasuhan, kekerasan dalam pengasuhan, dan agresivitas pada anak usia sekolah. Jurnal IImu Keluarga \& Konsumen, 11(3), doi:10.24156/jikk.2018.11.3.181

Qi, D., \& Wu, Y. (2020). Family's social economic status and child educational outcomes in China: The mediating effects of parenting practices and children's learning attitudes. Children and Youth Services Review, 118,
105387.

doi:10.1016/j.childyouth.2020.105387

Rahmat, S. T. (2019). Peran keluarga sebagai basis pembentukan karakter anak dalam menyongsong era bonus demografi. Jurnal Lonto Leok Pendidikan Anak Usia Dini, 2(1), 1-20.

Ramdani, Z., Supriyatin, T., \& Susanti, S. (2018). Perumusan dan pengujian instrumen alat ukur kesabaran sebagai bentuk coping strategy. Jurnal Psikologi Islam Dan Budaya, 1(2), 97-106. doi:10.15575/jpib.v1i2.2955

Rowe, M. L. (2008). Child-directed speech: Relation to socioeconomic status, knowledge of child development and child vocabulary skill. Cambrige University Press, 35(2008), 185-205. doi:10.1017/S0305000907008343

Rukmana, U. K., \& Indawati, R. (2014). Kondisi sosioekonomi dan demografi keluarga pra sejahtera dan sejahtera 1. Jurnal Biometrika dan Kependudukan, 3(1), 88-95.

Santrock, J. W. (2011). Life-span development (15th ed.). New York: McGraw-Hill.

Saputro, H., \& Talan, Y. O. (2017). Pengaruh lingkungan keluarga terhadap perkembangan psikososial pada anak prasekolah. Journal of Nursing Practice, 1(1), 1-8.

Satrianingrum, A. P., \& Andriyanti, E. (2020). Resiko pengasuhan permisif orang tua dan nenek pada pencapaian bahasa anak. Jurnal IImu Keluarga \& Konsumen, 13(3), 239-249. doi:10.24156/jikk.2020.13.3.239

Sifers, S. K. (2012). Measuring spirituality in children. Journal of Psychology and Christianity, 31(3), 209-218.

Solihin, R. D. M., Anwar, F., \& Sukandar, D. (2013). Kaitan antara status gizi, perkembangan kognitif, dan perkembangan motoric pada anak usia prasekolah. Nutrition and Food Research, 36(1), 62-72.

Tsania, N., Sunarti, E., \& Krisnatuti, D. (2015). Karakteristik keluarga, kesiapan menikah istri, dan perkembangan anak usia 3-5 tahun. Jurnal IImu Keluarga \& Konsumen, $\quad 8(1), \quad$ 28-37. doi:10.24156/jikk.2015.8.1.28

Wahhab. (2020). Apa itu bina keluarga balita atau BKB?. Dinas Pengendalian Penduduk KB Pemberdayaan 
Masyarakat \& Desa Kab. Bantul. Retrieved from https://dppkbpmd.bantulkab.go.id/apaitu-bina-keluarga-baliata-atau-bkb/ (Diakses tanggal 21 Juli 2021)

Wahyuningsih, F., Wahyuni, S., Widianto, E. (2020). Implementation of bina keluarga balita development program: Efforts to strengthen parents' ability in caring for children. Journal of Nonformal Education, 6(2), 176-184. doi:10.15294/jne.v6i2.25185

Xia, X. (2020). Parenting style and Chinese children's school readiness outcomes: The moderating role of socioeconomic status. Children and Youth Services Review, 105381. doi:10.1016/j.childyouth.2020.105381

Yachina, N. (2015). The problem of spiritual and moral formation of personality. Procedia Social and Behavioural Sciences, 197, 1575-1579.
Ye, M., Hu, Y., Xue, Q., Liang, A, \& Lu, Z. (2021). Understanding and change Parents' perspectives of their selfpoisoning children: A phenomenological study. International Emergency Nursing, 59(November), 101074. doi:10.1016/j.ienj.2021.101074

Zhao, X., \& Yang, J. (2021). Fostering creativity thinking in the family: The importance of parenting styles. Thinking Skills and Creativity, 41 , 100920. doi:10.1016/j.tsc.2021.100920

Zhuravlyova, I., \& Zhuravlyov, S. (2015). Humanistic sense of creativity in professional university education: The role of creativity in forming innovation model and modernization of university training. Procedia Social and Behavioural Sciences, 206, 445-454. doi:10.1016/j.sbspro.2015.10.081 